\title{
Evaluation of Subgrade Soils using California Bearing Ratio (Cbr) in Parts of Rivers State
}

\author{
${ }^{* 1}$ EKEOCHA, NE; EGESI, N \\ Department of Geology, University of Port Harcourt \\ PMB 5323, Port Harcourt \\ nnamdi.ekeocha@uniport.edu.ng, ${ }^{2}$ ndukuba.egesi@uniport.edu.ng
}

KEYWORDS: Subgrade soils, California Bearing Ratio (CBR) test, Plasticity Index (PI), Rivers State, Nigeria.

\begin{abstract}
Subgrade soils are characterized by their resistance to deformation under load, which can be a measure of strength (stress needed to break a material) or stiffness (the relationship of stress and strain in the elastic range or how well a material is able to return back to its original shape and size after applying stress). The greater the resistance to deformation a subgrade is the more load it can support before reaching a critical deformation value. The California Bearing Ratio (CBR) test is a simple strength test that compares the bearing capacity of a soil with that of a well graded crushed stone (a high quality crushed stone material should have a CBR of 100). The collected soil samples were taken to the laboratory for the 24 hours soaked California Bearing Ratio (CBR) test, Standard Proctor Compaction, moisture content and classification. These various tests were carried out according to AASHTO 1993, ASTM D-1883 and BS 1377 standard test procedures. The California Bearing Ratio (CBR) of the samples range from $12-34 \%$. The plasticity index (PI) of the samples fall within $10-20 \%$. The study has established the need for the upgrade of the performance of the studied material for use as subgrade. In view of this fact therefore, possible options of upgrade were considered in line with economic considerations. The two options that are fit for the upgrade are the over - excavation and stabilization options. The over - excavation method of enhancement of the performance of the subgrade materials that have been studied will require the excavation of the sub- grade soil to the depth of $0.7 \mathrm{~m}$ and the subsequent replacement with higher quality materials. The stabilization method prescribed will require addition of asphalt as the binder. The choice of method adopted shall strictly be guided by the cost implication of the implementation of the method. () JASEM
\end{abstract}

\section{http://dx.doi.org/10.4314/jasem.v18 i2.5}

Introduction: The California Bearing Ratio (CBR) was developed by the California State Highways Department to evaluate the strength of road subgrades. According to Krynine and Judd (1957) and Garg (2009), it is widely used in the design of flexible airport and highway pavements and sometimes in the specifications for the use of earth materials for various construction purposes. It is considered to give reliable results, provided the tests are conducted according to specified conditions. The higher the CBR value, the better the material, provided other necessary parameters like liquid limit and plasticity index are in conformity with the relevant regulatory specifications.

Subgrade soils are typically characterized by their resistance to deformation under load, which can be a measure of strength (stress needed to break a material) or stiffness (the relationship of stress and strain in the elastic range or how well a material is able to snap back to its original shape and size after applying stress). The greater the resistance to deformation a subgrade shows the more the load it can support before reaching a critical deformation geomorphic unit (Fig.1). value. The area under study is an economically important area to the nation, first considering the volume of vehicular movement regarding the oil and gas exploration and exploitation activities and secondly as a result of farm produce from the region to other parts of the country. The incessant failure of this road which basically connects the western part of the country gives credence to this as it is expected to establish the fitness state and proffer solutions where shortfalls are established.

Location And Geology Of Study Area: The study was carried out in areas with geographical coordinates of between $6^{\circ} 53^{\prime}$ and $7^{\circ} 05^{\prime} \mathrm{E}$ and between $4^{\circ} 40^{\prime}$ and $4^{\circ} 55^{\prime} \mathrm{N}$ parts of Rivers State within the Niger Delta region of Nigeria. The areas are located along airport road Port Harcourt and Khana along Port Harcourt Uyo express road. The geomorphic of the units are active/abandon coastal beaches, saltwater or mangrove swamp, freshwater swamps, back swamps, alluvial plain sand meander belt, submarine warm deltaic plain with abundant freshwater swamps and dry flatland and plains. The study area lies within the dry flatland and plains 


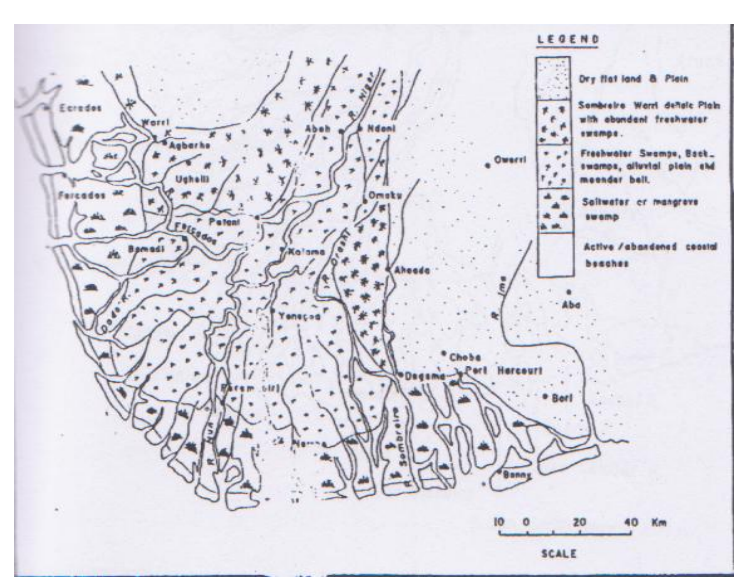

Fig 1.Major Geomorphic units of the Niger Delta after Short and Stauble, 1967.

Geologically, the study area falls within the coastal plain sands (Benin Formation), which form part of the Niger Delta and is marked by unconsolidated sands that range texturally from fine to very coarse. This horizon forms the zone of groundwater extraction within the region. The area is shown on the geological map of Rivers State by Local Government Area (Fig. 2).

\section{MATERIALS AND METHOD}

Disturbed soil samples were collected from eight locations and taken to the laboratory for the 24 hours soaked California Bearing Ratio (CBR) test, Standard Proctor Compaction, moisture content and consistency testing. These various tests were carried out according to ASTM D-1883 and BS 1377 standard test procedures.

The California Bearing Ratio (CBR) test is a strength test that compares the bearing capacity of a soil with that of a well graded crushed stone (thus a high quality crushed stone material should have a CBR of $100 \%$ ). The basic CBR test, which was carried out on compacted samples in the laboratory, in the soaked state, consists of causing a plunger of standard area to penetrate a sample. The load required to cause the penetration is plotted against measured penetration heavy traffic.

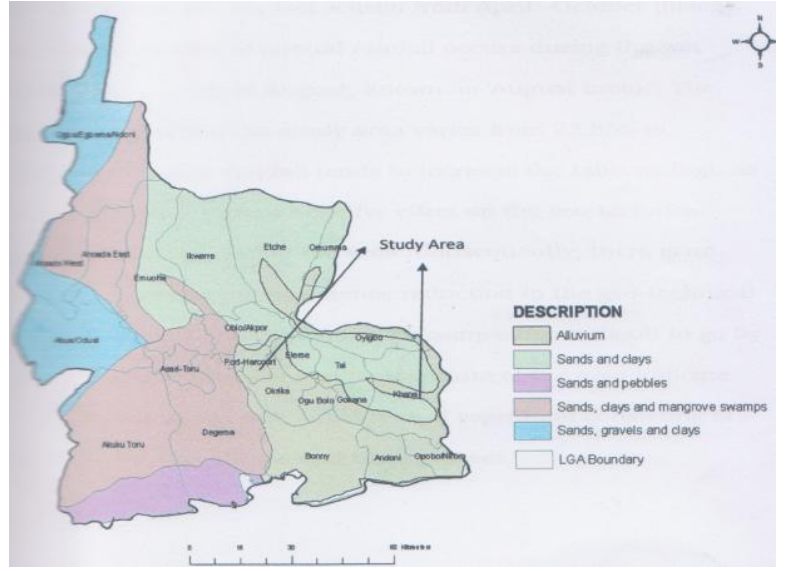

Fig 2. Geologic map of Rivers state after Nigerian Geological Survey Agency, 2006

with the readings noted at regular intervals of time. The analysis was carried out according to BS 1377: Soils for civil engineering purposes: Part 4, Compaction related tests.

\section{RESULTS AND DISCUSSION}

The various results of the analysis are shown in Table 1 below.: The results show that the samples have liquid limit values of between 35 and $44 \%$, Plastic limits of 21 to $30 \%$ with corresponding plasticity index values of between 11 and 14\%; while the optimum moisture content (OMC) ranged between 10.4 and $19.2 \%$ with maximum dry densities (MDD) of between 1.71 and $1.97 \mathrm{~kg} / \mathrm{m}^{3}$ respectively. The soaked CBR values of the samples on the other hand were between 12 and 34\%. The samples which classify as clayey sand (SC) on the USC scheme recorded $\mathrm{CBR}$ values ranging between $12 \%$ and $34 \%$. These values conform to the values associated with soils that classify between clayey sand and clayey gravel (SC and GC) according to the Colorado Asphalt Pavement Association (CAPA 2000) and by implication classifies as material with good subgrade strength, where capping may ordinarily be unnecessary except when the road will be exposed to

Table 1: Results of Analysis

\begin{tabular}{|c|c|c|c|c|c|c|c|c|c|}
\hline \multirow[t]{2}{*}{ Sample identity } & & 2 & 3 & & & & & & \multirow[b]{2}{*}{ FGN 1997} \\
\hline & 1 & & & 4 & 5 & 6 & 7 & $\overline{8}$ & \\
\hline Liquid limit (\%) & 36 & 35.4 & 35.4 & 36 & 41 & 38 & 37 & 44 & 30 \\
\hline Plastic limit (\%) & 23 & 23.6 & 21.3 & 24 & 25 & 24 & 24 & 30 & - \\
\hline Plasticity index (\%) & 13 & 12 & 14 & 14 & 16 & 14 & 13 & 14 & 13 \\
\hline Mdd (kg/dm3) & 1.86 & 1.88 & 1.97 & 1.94 & 1.71 & 1.82 & 1.83 & 1.87 & - \\
\hline Omc $(\%)$ & 13.5 & 13.4 & 14.3 & 11.5 & 19.2 & 13.9 & 12.4 & 10.4 & - \\
\hline $\operatorname{Cbr}(\%)$ & 27 & 25 & 26 & 34 & 13 & 12 & 22 & 17 & $5-11$ \\
\hline
\end{tabular}

The CBR values of the samples also conform to the specification of the Federal Government for Pavement Design [5-11\%]. The liquid limit with 35-
$44 \%$ value range exceed those specified by the Federal Government [30\%] and Plasticity Index values [11-16\%] also exceed those specified by the 
Federal Government [13\%] except at three locations where the values were lower than or equal to the prescribed value. This suggests that the samples are of poor quality, thereby supporting the observed trend of pavement failure within the region of study.

There is therefore need to improve on the quality of the materials in order for the road to be able to effectively withstand the heavy traffic that it is usually exposed to. This improvement may take the form of either or a combination of techniques namely removal and replacement (over - excavation), stabilization with a binding material for instance cement, which can stabilize all soils except the highly organic clays (Garg, 2009), or asphalt or the introduction of an additional base layer. This will however be given consideration in the design for a satisfactory service delivery.

These improvement techniques can compensate or upgrade subgrade soils of marginally poor performance. The choice of technique will be dependent on the results of the preliminary tests that will be carried in compliance with the relevant regulatory specifications, with adequate consideration of the traffic the road will be exposed to.

Conclusion: The study has established that the samples are of poor quality and as such will need improvement for the material to be considered for use as subgrade. In view of this fact therefore, possible options of improvement were considered in line with economic considerations. The two options that are fit for the upgrade are the over - excavation and stabilization options. The over excavation method of enhancement of the performance of the subgrade materials that have been studied, will require the excavation of the subgrade soil to the depth of $0.7 \mathrm{~m}$ and the subsequent replacement with higher quality materials. The stabilization method prescribed will require addition of asphalt. The choice of method adopted shall strictly be guided by the cost implication of the implementation of the method.

\section{REFERENCES}

American Society for Testing and Materials (ASTM, 1975). Special procedures for testing soils and rocks for engineering purposes. Technical Publication, No. $479,5^{\text {th }}$ ed.

British Standard Institution (BS, 1377) 1975. Methods of Testing for Soils for Civil Engineering Purposes. British Standard Institution, London. 20

Colorado Asphalt Pavement Association (CAPA), 2000: Guideline for the Design and Use of Asphalt Pavements for Colorado Roadways. CAPA. Englewood, CO.
Etu-Efeotor, J.O. (1997). Fundamentals of Petroleum Geology, Paragraphics, Rivers.

Garg, S. K., 2009. Soil Mechanics and Foundation Engineering, $7^{\text {th }}$ ed. Khanna Publishers, New Delhi. 673-683pp.

Ibrahim, A., 1983: Back Cotton Soil in Road Pavement Design, Construction and Performance, In S. A. Ola (ed.). Tropical Soils of Nigeria in Engineering Practices: A. A. Balkema, Rotterdam, Netherlands.

Krynine, D. P. and William, J. R. 1957: Principles of Engineering Geology and Geotechnics. McGraw - Hill Book Company, NY. 159, 537pp.

Murthy, V. N. S., 2008. Textbook of Soil Mechanics and Foundation Engineering. CBS Publishers \& Distributors, New Delhi, India. 84 - 100pp.

Nigerian Federal Ministry of Works, 1997. General specification for roads and bridge works. Federal Government of Nigeria.

Nigerian Geological Survey Agency NGSA 2006. Geological and Mineral Resources of Map of Nigeria.

Ola, S. A., 1983: Flexible Pavement Maintenance for Tropical Highways In S. A. Ola (ed.), Tropical Soils of Nigeria in Engineering Practices. A. A. Balkema, Rotterdam, Netherlands.

Omotosho, O, 2006. Low cost soil improvement techniques for road construction in weak soil strata. Unpub. Lecture at 3-day workshop on Preparing Appropriate Specifications for Road works in Riverine Areas by Nigerian Institution of Civil Engineers in collaboration with Techgrade Consulting. 22-24 ${ }^{\text {th }}$ August 2006, Port Harcourt.

Smith, R. B., 1988: Loading Characteristics of a Tertiary Clay and Implications for Road pavement Design. No 37/988. Bull IAEG, 137 $141 \mathrm{pp}$.

Short, K. C., and Stauble, A. J.,1967. Outline of Geology of Niger Delta. Am. Assoc. Petroleum Geologists Bull. Vol.51, p.761 - 779 . 